$10-2018$

\title{
The Fine Print of the Mexican Energy Reform
}

Guillermo J. Garcia Sanchez

Texas A\&M University School of Law, ggarciasanchez@law.tamu.edu

Follow this and additional works at: https://scholarship.law.tamu.edu/facscholar

Part of the Comparative and Foreign Law Commons, Energy and Utilities Law Commons, Natural Resources Law Commons, Oil, Gas, and Mineral Law Commons, and the Transnational Law Commons

\section{Recommended Citation}

Guillermo J. Garcia Sanchez, The Fine Print of the Mexican Energy Reform, in Mexico's New Energy Reform 36 (Duncan Wood eds., 2018).

Available at: https://scholarship.law.tamu.edu/facscholar/1238

This Book Section is brought to you for free and open access by Texas A\&M Law Scholarship. It has been accepted for inclusion in Faculty Scholarship by an authorized administrator of Texas A\&M Law Scholarship. For more information, please contact aretteen@law.tamu.edu. 
The Wilson Center, chartered by Congress as the official memorial to President Woodrow Wilson, is the nation's key non-partisan policy form for tackling global issues through independent research and open dialogue to inform actionable ideas for Congress, the Administration, and the broader policy community.

Conclusions or opinions expressed in Center publications and programs are those of the authors and the speakers and do not necessarily reflect the views of the Center staff, fellows, trustees, advisory groups, or any individuals or organizations that provide financial support to the Center.

The Mexico Institute of the Woodrow Wilson International Center for Scholars seeks to improve understanding, communication, and cooperation between Mexico and the United States by promoting original research, encouraging public discussion, and proposing policy options for enhancing the bilateral relationship. A binational Advisory Board, chaired by Ambassador Earl Anthony Wayne and Dr. Luis Téllez, oversees the work of the Mexico Institute.

\author{
Mexico Institute \\ Woodrow Wilson International \\ Center for Scholars \\ One Woodrow Wilson Plaza \\ 1300 Pennsylvania Avenue NW \\ Washington, DC 20004-3027
}

\author{
www.wilsoncenter.org/mexico \\ mexico@wilsoncenter.org \\ facebook.com/Mexicolnstitute \\ @Mexicolnstitute
}

202-691-4130 


\section{Table of Contents}

Introduction $\ldots \ldots \ldots \ldots \ldots \ldots \ldots \ldots \ldots \ldots \ldots \ldots \ldots \ldots \ldots \ldots \ldots \ldots \ldots \ldots \ldots \ldots \ldots \ldots \ldots \ldots$

Duncan Wood

The Evolving Global Energy System. $\ldots \ldots \ldots \ldots \ldots \ldots \ldots \ldots, \ldots, \ldots, \ldots, \ldots, \ldots, \ldots, 5$

Sarah Ladislaw and Jesse Barnett

Of Paradigm Shifts and Political Conflict: The History of Mexico's Second Energy Revolution . . . . 17 Duncan Wood and Jeremy Martin

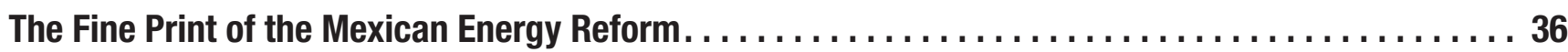
Guillermo José García Sanchez

The Politics of Oil in Mexico: Consolidating the Reforms $\ldots \ldots \ldots \ldots \ldots \ldots \ldots \ldots \ldots \ldots \ldots \ldots \ldots$ Jeremy Martin

A Crude Reform: Pemex in Mexico's New Energy Landscape $\ldots \ldots \ldots \ldots \ldots \ldots \ldots \ldots \ldots \ldots \ldots, 78$ Leticia A. Abad and Noel Maurer

Initial Results from the Mexico Electricity Reform, 2013-18 $\ldots \ldots \ldots \ldots \ldots \ldots \ldots \ldots \ldots \ldots \ldots \ldots \ldots \ldots$ Peter Nance

Mexico's Renewable Energy Future. $\ldots \ldots \ldots \ldots \ldots \ldots \ldots \ldots \ldots \ldots \ldots \ldots \ldots \ldots \ldots \ldots \ldots \ldots \ldots \ldots, 146$ Lisa Viscidi

An Uncertain Future: The Energy Sector under AMLO $\ldots \ldots \ldots \ldots \ldots \ldots \ldots \ldots \ldots \ldots \ldots \ldots, 164$ Duncan Wood 


\section{The Fine Print of the Mexican Energy Reform}

\section{Guillermo José García Sanchez, Associate Professor, Texas A\&M University School of Law}

$\mathrm{F}$ ive years ago, when Mexico transformed its energy sector, most commentators were worried about the government's capacity to implement the reform. What would the upstream contracts look like? Would the auctions be transparent? How would international companies react? After two successful auction rounds, 107 signed contracts, and the creation of viable regulatory agencies to manage and monitor the reform agenda, the questions have changed. Today, Mexico's capacity to implement energy reforms and attract foreign investment is no longer in doubt. Today, the most pressing questions about the reform concern its long-term sustainability. Can it survive Mexican electoral cycles? Will Mexico continue down the same road that fosters private participation in the development of new fields? How safe are the current investments in Mexico from the rise of populism and nationalism in the Mexican political narrative? ${ }^{70}$ In other words, moving forward, are the necessary legal pillars cemented in place firmly enough to survive any political hurricane?

The legal response to these questions, as with many legal issues, is unclear. The reform included not only the oil and gas sectors but also the production and distribution of energy around the Mexican territory. ${ }^{71}$ This chapter cannot fully address all of the sectors covered by the reform; rather, it will focus on why the legal architecture of the energy reform for upstream activities is not as "bulletproof" and "irreversible" as some Mexican officials claim. ${ }^{72}$ Two weak points may prevent the reform from achieving its desired long-term stability. First, the heart of the energy reform is located not in the text of the constitution, but in the transitory articles of the reform. The president's legal team decided to insert the substantial terms of the reform-especially the type of contracts that the state could sign_ as "transitory" articles rather than choosing to fight the political battles needed to make them constitutional provisions. The second and perhaps the biggest weakness of the reform was the designers' inability to surpass the legal culture that surrounds Mexico's tradition of hyper-presidentialism. Mexican presidentialism tends to consolidate state power in the president as the central figure in determining public policy, as opposed to relying on independent agencies to control the key policy decisions in their assigned areas of oversight.

This second point deserves greater attention. For political and strategic reasons, the "founding fathers" of the reforms made sure that the president ultimately has control of the future of the energy sector. He or she might

70 See the special "Latin America First?" edition of Americas Quarterly, www.americasquarterly.org/content/latin-america-first. According to the March 2018 Goldman Sachs report on Mexico, "AMLO [Andrés Manuel López Obrador] could change the oil sector status quo by slowing down the implementation of the energy sector reform, making it less predictable and market friendly, and by intervening more in the sector directly, and indirectly by giving more money, power, and influence to the inefficient state-oil concern, Pemex." See Alberto Ramos, Paulo Mateus, and Gabriel Fritsch, "Mexico: Facing 100 Days of Uncertainty and Potential Drama," Goldman Sachs Economics Research, March 23, 2018, www.lapoliticaonline.com.mx/files/content/110/110415/Mexico_Facing_100_days_of_Uncertainty_and_Potential_Drama.pdf.

71 "Decreto por el que se reforman y adicionan diversas disposiciones de la Constitución Política de los Estados Unidos Mexicanos, en Materia de Energía, DOF (Edición Vespertina), 2 (20 de diciembre de 2013)," December 20, 2013, http://dof.gob.mx/nota_detalle. php?codigo=5327463\&fecha $=20 / 12 / 2013$ (hereafter, Constitutional Reform).

According to Mexican energy minister Pedro Joaquin Codwell, who is also the chair of Pemex's board of directors, the energy reform is “'irreversible' as its major tenets are enshrined in the constitution, and would require a super-majority in Congress to reverse." See Ana Isabel Martinez, "Mexico Energy Minister Says Election No Obstacle to 2018 Oil Auctions," Reuters, February 9, 2018, www.reuters.com/article/usmexico-energy/mexico-energy-minister-says-election-no-obstacle-to-2018-oil-auctions-idUSKBN1FT2N2. 
be constrained in the ability to modify existing contracts, but a new president surely can put the brakes on future projects, planned bidding processes, and the participation of private actors in the next stages of the reform. When it comes to the oil and gas sector, private actors might be constitutionally authorized to sign contracts with the state, but the president is still the one in control of the terms of the agreements, the tax regime attached to them, and even the possibility that new fields may be open for exploration. The new agencies, notably the National Hydrocarbons Commission (Comisión Nacional de Hidrocarburos; $\mathrm{CNH}$ ), do not have the complete independence to choose the partners of the Mexican state or ensure that the decisionmaking process will be transparent. The executive power holds the paper, the pen, and even the key to the room where the contract will be signed. From a policy standpoint, Mexico might not be open for business in the next exploration and production $(\mathrm{E} \& \mathrm{P})$ development stages. It will all depend on whether the next president decides if it is in Mexico's national interest to invite private actors or to assign the new fields to Pemex.

\section{Transitional Constitutional "Safeguards"}

The energy reform proposal of 2013 sparked a debate among legal scholars on whether the reform was modifying the constitutional order substantially. ${ }^{73}$ President Peña Nieto and his team of experts were keen to point out that the reform was in fact following the vision of the last president of the Mexican revolution, President Lázaro Cárdenas. ${ }^{74}$ Peña Nieto's team proposed to reinsert the wording in the constitution that Cárdenas had employed to constitutionalize the expropriation of the oil industry back in $1938 .{ }^{75}$ The Cárdenas reform textually prohibited the state from giving concessions to private parties for the production of hydrocarbons but retained the possibility for the government to sign other types of contracts with them. ${ }^{76}$ In other words, it would be constitutionally permissible to contract with private parties, but not to give concessions to them. "It wasn't until the beginning of the 1960s when an amendment was enacted that the constitution prohibited the signing of any contracts with private parties and reserved all of the hydrocarbon-related activities to Pemex," Peña Nieto explained in his 2013 speech introducing the reform. ${ }^{77}$ Ironically, in the view of the Peña Nieto administration, the reform reestablished the 1938 legal regime to introduce Mexico to the 21st-century energy revolution.

In the view of the administration, this unusual way of amending the constitution disarmed any argument from the congressional opposition that the administration had violated the spirit of the 1938 expropriation and the values of the national revolutionary identity. ${ }^{78}$ However, it was a strategic mistake. The Peña Nieto administration did not specify in the constitutional text what type of contracts could be signed by the state. The

73 See, for example, George Baker, "Concesión 'vs' licencia” [Concession vs. license], Milenio Diario, June 29, 2015, www.milenio.com/firmas/george_baker/Concesion-vs-licencia_18_545525470.html.

74 "Palabras del Presidente Enrique Peña Nieto, durante la Presentación de la Iniciativa de Reforma Energética" [Speech of President Peña Nieto introducing the energy reform initiative], August 12, 2013, www.gob.mx/presidencia/prensa/palabras-del-presidente-enrique-pena-nieto-durantela-presentacion-de-la-iniciativa-de-reforma-energetica. 


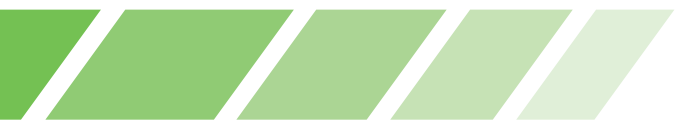

amendment did not define what a concession is, nor did it state the terms of the other types of contracts. ${ }^{79}$ The administration left it to the transitory articles to establish the type of contracts that the constitution did not define. Legally, this left open the possibility for contradictions among the constitutional text, the transitional provisions, and the secondary regulation. Ultimately, these contracts in the transitory regime are the most important element that defines the legal relationship between the state and the private actor and they become the main source of investors' rights. ${ }^{80}$

\section{Are they Concessions or Licenses?}

Upstream activities have changed radically since the 1910s when the Mexican revolutionaries were drafting the Mexican Constitution. In those days, the most common (and one could argue almost the only) contractual relationship between states and companies was the classic concession arrangement. ${ }^{81}$ These concessions allocated E\&P rights over vast areas for long periods of time to one single company and granted title to the resources in situ (in the ground). ${ }^{82}$ These concessions contracts typically reserved few rights to the state "except for the right to receive a payment based upon production," usually in the form of income tax and royalties. ${ }^{83}$ The essential characteristic of the early concession agreement was that the "concessionaire enjoy[ed] a nearly total freedom" and control over the resources in all facets of the petroleum operations. ${ }^{84}$ For example, before the 1938 nationalization, the British-controlled Mexican Eagle Oil Company had a concession over all federally owned lands along the Gulf of Mexico. ${ }^{85}$

79 The constitution does not specify what a concession is. Neither the transitory articles nor the Hydrocarbons Law passed after the reform specify it. The Hydrocarbons Law defines only E\&P assignment and contract ("Assignments: the legal administrative act in which the Federal Executive gives exclusive rights to the assignment recipient to engage in Exploration and Exploitation of hydrocarbons in a Contractual Area for a specific time") (Exploration and Extraction Contract: a legal act in which the Mexican State, through the National Hydrocarbons Commission, agrees to the Exploration and Extraction of hydrocarbons in a contractual area for a specific period of time.").

80 As stated by F. Rouhani in the context of the Iranian legislation, "The Petroleum Act lays down the general principles under which agreements may be made, and described the varieties of authorized relationships, but once an agreement is made and is ratified by the Legislature, the Petroleum Act virtually fades away because the agreement itself is the appropriate and sufficient law." See F. Rouhani, International Agreements and Contracts in the Field of Petroleum 9 (United Nations Inter-Regional Seminar on Techniques of Petroleum Development, January 23-February 21, 1962).

81 Ernst E. Smith et al, International Petroleum Transactions, 3rd ed., (Westminster, CO: Rocky Mountain Mineral Law Foundation, 2010 ), 429 ("Early grants of mineral rights were made through classic concession agreements. The characteristics of this agreement were: (1) a grant of rights to mineral development over vast acreage; (2) for a relatively long period; (3) providing to the IOC extensive control over the schedule and manner in which the mineral reserves were developed, and (4) reserving few rights to the sovereign, except the right to receive a payment based upon production.")

Ibid, 429.

Ibid.

Saudi Arabia v. Arabian American Oil Co. Award, 27 I.L.R. 117, 161 (August 23, 1985) ("The concessionaire enjoys a nearly total freedom, and is neither bound by clauses concerning maximum tariffs for sales nor prohibitions of preferential tariffs, which are the usual features of the cahiers des charges in public service concessions. Mining concessions are not public works concessions either, because the mineral deposits become the property of the concessionaire who, at the end of his concession, will have to return them to the State with their exploitable substance diminished and sometimes even exhausted."). See also Zhiguo Gao, International Petroleum Contracts, Current Trends and New Directions (London: Graham \& Trotman, 1994), 12-13.

85 George Philip, Oil and Politics in Latin America: Nationalist Movements and State Companies (Cambridge, UK: Cambridge University Press, 1982); and Jesús Silva Herzog, Historia de la expropiación de las empresas petroleras [History of the expropriation of oil companies] (Mexico City: Instituto Méxicano de Investigaciones Económicas, 1964), 18-32. 
In contemporary E\&P agreements signed between states and private companies, the terms concessions, licenses, and even E\&P agreements are "often used interchangeably." 86 In the words of Gordon Barrow, "there are a number of synonyms for this instrument [concession], such as permit, license and lease." ${ }^{87}$ Modern concessions around the globe minimize or eliminate the broad terms of the classic concessions and expand the government's control over the private companies' operations. ${ }^{88}$ Worldwide, one could easily find contracts that are called "concessions" but that no longer give the private company total control of the resource. These contracts will have, among others things, various levels of government control, different initial terms of operation, different minimum exploratory work obligations, different work plans approved by the ministries in charge of supervision, and differing commitments to specific plans for developing the resources, including terms for the relinquishment of the area ${ }^{89}$ Moreover, contemporary concessions "include bonuses payable on signature of the agreement, on discovery of a petroleum field or on reaching certain levels of production." ${ }^{90}$ In other words, today the term concession is vague. Without a proper legal definition, as in the Mexican energy reform constitutional text, the term leaves unclear the type of contractual relationship that will emerge between the state and the private party. This is where the transitory articles come into play.

The fourth transitory article specifies that the Mexican Congress must regulate the type of contracts that the government can sign with private companies that would exploit the national resources on behalf of the nation. Moreover, the transitional provision ties the hands of Congress by stating that these contracts "should be, among others: service agreements, profit or production sharing, or licenses." ${ }^{11}$ In terms of the state considerations, the transitory article states that these should be: "I) cash for the services contracts; II) a percentage of the profit, for the profit-sharing agreements; III) a percentage of the production, for the production-sharing agreements; IV) with the onerous transfer of hydrocarbons after being extracted from the underground, in the case of licenses, or $\mathrm{V}$ ) any combination of the above." 92 Instead of giving temporary instructions to Congress on regulating the constitutional reform, the transitional provisions gave specific instructions on the substance of the legislation that Congress had to adopt.

86 Smith et al., International Petroleum Transactions, 443; another example of how they are used interchangeably can be found in Carmen Otero García-Castrillón, "Reflection on the Law Applicable to International Oil Contracts," Journal of World Energy Law \& Business 6, no. 2 (2012) 133.

87 Gordon Barrows, "A Survey of Incentives in Recent Petroleum Contracts," in Petroleum Investment Policies in Developing Countries, edited by Nicky Beredjick and Thomas Wälde (London: Graham \& Trotman, 1998), 226.

Smith et al., International Petroleum Transactions, 443.

Carol Nakhle, "Petroleum Fiscal Regimes: Evolution and Challenges," in Taxation of Petroleum and Minerals: Principles, Problems and Practice, edited by Philip Daniel, Michael Keen, and Charles McPherson (London, Routledge, 2010), 89 and 95.

Ibid. For instance, in the case of the United States, the current leasing regime is a form of concession ("generally, federal offshore leases, a form of concession, include the following terms and provisions: a leasehold consisting of a compact area not exceeding 5,760 acres; a lease primary terms of five years (up to ten years for certain deep water leases) and a habendum clause providing for a secondary term for so long as oil or has is produced in paying quantities or approved drilling or well reworking operations are being conducted; payment of the amount or value specified by the bidding system; the right to explore, develop, and produce oil and gas conditioned upon due diligence requirements and upon approval of a plan of payment of royalties; and offers of production to small or independent refiners."). See Owen L. Anderson and Christopher Kulander, The Offshore Petroleum Licensing Regime in the United States, in Regulation of the Upstream Petroleum Sector: A Comparative Study of Licensing and Concession Systems, edited by Tina Hunter (Cheltenham, UK: Edward Elgar, 2015), 167. 




Regarding the type of contracts that must be included in the secondary legislation, the transitional provisions look similar to modern concessions or licenses elsewhere in the world. Moreover, transitory article 5 gives the substantive right to international companies to report or book expected benefits for accounting and financial purposes from these contracts. In other words, the so-called licenses authorized by the transitory article look like contemporary concession agreements. ${ }^{93}$ The only fundamental difference being that the hydrocarbons are transferred to the company once they are extracted, as opposed to in situ, and upon payment of the royalties. ${ }^{94}$ However, just like the modern concession, in the Mexican license the private operator bears all the costs and risks and retains the exclusive right to explore and extract the hydrocarbons located in a specified area. ${ }^{95}$ As stated by the renowned legal scholar Diego Valadés, "in one section of the Constitution, contracts with the name concession will be denied, and then in another section, they will be allowed under an equivalent denomination." 96

One reading of these provisions is that President Peña Nieto and his team were unable to include the modern type of concessions in the constitution. Put differently, they did not fix the most critical source of substantive rights to private companies in the text of the constitution; rather, they did it in its transitional provisions. Perhaps the Peña Nieto administration feared the political turmoil that the term could generate. Instead, they enacted them in the transitory articles hoping that they would be less controversial. They treated the constitution not as the supreme law of the land, but rather as an adhesion contract that hid the most important terms in the fine print, hoping that the other party would not realize it until it was too late.

\section{Transitory Articles as a Fine Print}

Is hiding the substantive rights of important constitutional reforms in the transitory articles a regular parliamentary practice in Mexico? No. Good legislative practice dictates that it is not the nature of transitory articles to be the heart of a constitutional amendment. In civil law, a transitional section has the purpose of determining the enforcement of the approved legislation. ${ }^{97}$ Transitional provisions, for example, explain which laws are being revoked and substituted by the new law; they define who the enforcing authority will be, instruct agencies or Congress that they must pass specific legislation or allocate budget to give life to the reforms, and the like. They make sure that there is no legal "anarchy" between the time that the new law takes force and the old law is repealed..$^{98}$ In other words, they give the necessary details for the legislation to become a reality, they are temporary and auxiliary in nature, and hence they are not deemed to be the heart or central part of the

93 See comments from José Antonio Prado of Holland and Knight in Alejandra López, "Confunden términos licencia y concesión" [Confusing terms of license and concession], Reforma, June 8, 2015, www.reforma.com/aplicacioneslibre/articulo/default. aspx?id=560100\&md5=8651197a2972748724fcac21 ebf63411\&ta=0dfdbac11765226904c16cb9ad1b2efe\&po=4; and Alejandro Guzmán Rodríguez, “¿Contratos o Concesiones?” [Contracts or concessions?], Energía a Debate, n.d., www.energiaadebate.com/¿contratos-o-concesiones/. Ibid.

See, for example, Contract No. CNH-R01-L04-A1.CPP/2016 with China Offshore Oil Corporation E\&P Mexico, S.A.P.I. de C.V., Section 2.1, www.gob.mx/cms/uploads/attachment/file/198308/Contrato_Area_1_Cinturon_Plegado_Perdido.pdf. Ibid. en Materia Administrativa del Sexto Circuito, Tesis Aislada, VI.2o.A.1 K, Num. De Registro: 188686, Novena Época, Semanario Judicial de la Federación y su gaceta, Tomo XIV, Octubre de 2001. 
legislation. ${ }^{99}$ Some commentators argue that "once the transitory article serves its function it loses its efficacy, that is the reason why it cannot establish general provisions that are binding upon private individuals." 100 This is not the case of the transitional articles of the energy reform.

As mentioned above, the transitional provisions are the center of the reform. Out of the 6,900 words that make up the Mexican energy reform, 6,000 are located in the transitory articles. ${ }^{101}$ The core of the reform is not regulated in the constitution, but in these "provisional" articles. ${ }^{102}$ In a study by Diego Valadés, "out of the 21 transitory articles, eleven have important provisions that should be part of the constitutional text." ${ }^{103}$ It is here where the reader can find the type of E\&P contracts that the government can sign with private parties: license, production- and profit-sharing agreements, and service contracts. Moreover, it is in these "temporary" articles where companies are given the right to book the reserves awarded by the contracts. In other words, the heart and soul of the Mexican upstream energy reform is not in the constitution, but in these transitional provisions. In the words of Diego Valadés, "[i]n Mexico no one had ever used the transitory articles to mislead and conceal, like they did in the case of this reform." ${ }^{104}$ It is left to the Supreme Court of Mexico to determine the possible impact of modifying the nature of such transitional articles that potentially could contradict the constitutional text. $^{105}$

In the past, the Mexican Supreme Court has stated that the transitional provisions are part of the constitutional amendment in so far as they help to give life to it. ${ }^{106}$ Yet these rulings were mostly in the context of determining the obligations of certain authorities to pass secondary legislation or the timing of the legislation's entry into

99 Francisco Berlin Valenzuela, Diccionario de Términos Parlamentarios [Dictionary of parliamentary terms] (1997). ("Articulo transitorio. Disposición numerada en forma consecutiva de un tratado, leyo reglamento que tiene una vigencia momentánea o temporal. Su carácter es secundario, en la medida que actúa como auxiliar de los artículos principales, para precisar el momento de la entrada en vigor del nuevo texto legal o para determinar otras especificaciones sobre las condiciones en que la nueva legislación comenzará a surtir efectos legales.”). See also Sergio Nudelstejer, "Articulo Transitorio en México" [Transitory articles in Mexico], Enciclopedia Legal, http://mexico.leyderecho.org/articulotransitorio/\#Recursos (“En México, el término 'artículo transitorio' hace referencia a una disposición que se agrega después de que la materia a legislar ha sido tratada en su propio articulado y su efecto jurídico está limitado en el tiempo.")

100 Carla Huerta Ochoa, "Artículos Transitorios y Derogación" [Transitory articles and repeal], Boletín Mexicano de Derecho Comparado 102, https://revistas.juridicas.unam.mx/index.php/derecho-comparado/article/view/3693/4524. (Para conocer la naturaleza de los artículos transitorios no es necesario realizar un análisis semántico, pues el término transitorio es elocuente, de su denominación se infiere que la función de estos artículos es, en principio, temporal y sirve para regular los procesos de cambio en el sistema jurídico. Su naturaleza jurídica se define por su función que se refiere a la aplicabilidad de otras normas, ya sea al señalar la entrada en vigor de una disposición o al derogarla. El artículo transitorio pierde su eficacia una vez que ha cumplido su cometido, por ello es que no puede establecer prescripciones genéricas con carácter vinculante a los particulares.)

101 Valadés, "La Constitución desfigurada."

102 Ron Snipeliski Nischli calls the transitory articles "a new modality" of the constitutional legislator to "detail certain aspects of the constitutional text" in the "transitory" articles "which are not transitory at all, because they share the same nature and characteristics of other constitutional provisions" Ron Snipeliski Nischli, "Artículo 27," Constitución Política de los Estados Unidos Mexicanos Comentada, Vol. 1, edited by Jose Ramón Cossio Días (Mexico: Tirant lo Blanch, 2017), 558.

103 Valadés, "La Constitución desfigurada."

104 Ibid.

105 This is one of the consequences of including substantive rights in the constitution. See Snipeliski Nischli, "Artículo 27," 558.

106 Amparo en Revisión 1106/2015, resuelto 02/03/2016, Segunda Sala de la Suprema Corte de Justicia de la Nacional; see also Acción de Inconstitucionalidad 99/2016 y acumulada 104/2016 (regarding the electoral judges); Acción de Inconstitucionalidad 58/2016 (anticorruption law in Chihuahua); Acción de Inconstitucionalidad 56/2006 (anticorruption law in Veracruz). 
force. ${ }^{107}$ The Supreme Court has never resolved the possible result of a contradiction of substantive rights directly given to individuals in transitory articles — such as rights to private parties to book reserves — and the text of the constitution. A new government could argue in court that the constitutional text limits the rights of private parties to providing services to the state, contradicting the terms of the transitory articles that provide for licenses that give exclusive rights to exploit and extract hydrocarbon resources. We do not know how the Supreme Court will react if it is asked to determine whether the constitution contradicts substantive rights located in the transitory articles. But what we do know is that by "disfiguring the constitution," the legal engineers of the reform gave ammunition to the detractors to fight it out in courts. ${ }^{108}$ If the Peña Nieto administration had included everything in the text of the constitution, the available alternative for the detractors would be to fight for a constitutional amendment. However, with the adopted legal architecture, a new president could argue that the existing contracts violate the spirit of the constitution because, as he or she understands it, the terms are closer to the ones of a concession. Hence, the new president would not need to amend the constitution to challenge the existing contractual architecture of the reform.

\section{The President at the Helm of the Energy Reform}

Yet it is the structure of the decision-making process, not the transitional provisions, that may be the biggest challenge to the implementation of the new energy model. The designers of the reform ensured that the executive power played an important role in defining the direction, pace, and content of the energy sector in Mexico. ${ }^{109}$ At least three executive prerogatives hold the key to the future of the reform in the upstream sector: the power to determine the energy policy of the state, the prerogative to determine the areas and the contracts that will be open for auctions, and the authority to determine the financial and fiscal terms of the contracts. ${ }^{110}$ All three fall into the hands of ministries that are directly in control of the sitting president.

\section{SENER as the Master Key}

According to the constitutional design, the minister of energy, who is directly appointed by the president, has the power to "establish, conduct and coordinate the energy policy" in Mexico. ${ }^{111}$ When it comes to hydrocarbonrelated activities and the transition and distribution of energy, these are considered state "strategic" activities "of social interest and public order, and as a consequence will have preference over any other activity that benefits from the development of the surface or underground." 112

As a consequence, the minister of energy can decide which areas will be adjudicated by assignments to state production entities (mainly Pemex) and which will be contracted through auctions where private and state entities can participate (figure 3.1). The risk of the future of the energy reform lies in this division of tasks. Regardless of the existing contracts, the next government will have to decide whether new areas will be

107 Ibid.

108 Valadés, "La Constitución desfigurada."

109 See Snipeliski Nischli, "Artículo 27," 557.

110 Constitutional Reform, Article 6 Transitory and Article 10 Transitory.

111 Ibid., Article 10 Transitory.

112 Ibid., Article 18 Transitory. 
adjudicated to Pemex or be open for competition. The secondary legislation, the Hydrocarbons Law, tries to narrow the grounds in which the ministry can give assignments to Pemex by forcing it to justify its decision "as the most adequate mechanism for the interest of the State in terms of production and that guarantees the supply of hydrocarbons and that the recipient of the assignment has the technical, financial and execution capacity to extract the hydrocarbons in the most efficient and competitive way." ${ }^{113}$ In this adjudicative process, the National Hydrocarbons Commission $(\mathrm{CNH})$ must give its option by issuing a technical report. ${ }^{114}$ However, constitutionally, nothing prevents the new minister of energy from modifying the next rounds and the development plan set up by the previous administration in the name of "national interest." In case of inconsistency between the constitution and the secondary legislation, the federal courts could easily declare the secondary law as unconstitutional for limiting the powers of the executive contrary to the text and spirit of the reform.

Figure 3.1. Assignments

\section{Assignments}


The energy ministry's second power lies in its ability to design the content of the contracts and the technical guidelines of the bidding processes. The $\mathrm{CNH}$ can "technically assist" the minister of energy in defining these provisions, but the ultimate design is the ministry's responsibility. Once a new area is found, the ministry determines which type of contractual relationship will govern its development: assignments, production- or profit-sharing agreements, or licensees. The $\mathrm{CNH}$ is in charge of the auctions, the signing of the contract on behalf of the state, and most important of supervising and enforcing the terms of the agreement.

Perhaps the most important power of the $\mathrm{CNH}$ regarding long-term reform implementation lies here. If the companies fail to perform their duties under the contracts or in accordance with the law, only the CNH can cancel the contractual relationship under a set of preestablished grounds. ${ }^{115}$ Such grounds might include the possibility that the companies do not start operations in a particular period, do not invest in the field as agreed in the contracts, transfer contractual rights without authorization, have an accident that affects production and

113 Decreto por el que se expide la Ley de Hidrocarburos y se reforman diversas disposiciones de la Ley de Inversión Extranjera, Ley Minera, y Ley de Asociaciones Público Privadas), DOF: 11/08/2014 (hereafter, Hydrocarbons Law), Article 6.

114 Ibid.

115 Ibid., Article 20. 




is caused by negligence or fraudulent conduct, fail to report the appropriate information regarding production and costs to the authorities, or fail to produce payment to the state in accordance with the contract terms. ${ }^{116}$ According to the Hydrocarbons Law, these are the only grounds (unicamente is the term used in Spanish) to cancel an E\&P contract and relinquish the area without compensation. ${ }^{117}$ The procedure to determine a rescission of these contracts is considered an administrative act and is not subject to arbitration. In sum, the ministry of energy cannot cancel the existing 107 contracts; instead the $\mathrm{CNH}$ is the only body that can make this determination under the narrow circumstances established in the Hydrocarbons Law. ${ }^{118}$

Since the $\mathrm{CNH}$ is the one enforcing the contractual terms, it does have the duty of providing comments to the ministry of energy regarding a future contract. However, ultimately the contractual design is determined by the minister of energy. The only provisions of the agreements that do not fall under its powers are the ones related to finances and taxes. Here is where another office dependent on the president — the treasury-comes into play.

\section{The Power of the Executive Purse: A Shadow from the Old Regime}

It is well known that Pemex's terrible finances before the energy reform were not only the result of mishandling of resources inside the organization but also a consequence of the extreme control that the Mexican finance ministry exercised over the company's books. The government's primary sources of revenue came from taxes on Pemex. Hence, the ministry of energy had enormous influence over how the state-owned company's finances were administered. With the energy reform, the finance ministry's authority over the operation of hydrocarbons companies did not disappear. The reform gives exclusive powers to the ministry of finance to establish the "economic conditions for the bids and contracts [of the energy reform] in connection to the fiscal regime that will allow the Nation to obtain in time the profits that will contribute to long-term development." 119 As such, for each contractual arrangement the finance ministry is in charge of determining the standard royalties, corporate tax and costs deduction, and adjustable rates for royalties. This provision gives a robust control of the economics of the contracts to a single government office (figure 3.2). The treasury could make a particular project attractive to foreign investors or economically inefficient.

For example, the Hydrocarbons Income Law sets up a sliding-scale royalty with varying rates depending on the type of fields, their production rates, and the price of oil and gas. ${ }^{120}$ Some projects with narrower profits, such as shale gas, will have a royalty discount. ${ }^{121}$ The possible rise of royalty rates if production or prices increase will depend on each contractual arrangement. ${ }^{122}$ The finance ministry determines those rates after the ministry of energy designs the contract. Another example, found in Article 13 of the Hydrocarbons Income Law, states that

116 Ibid.

117 Ibid. (El Ejecutivo Federal, a través de la Comisión Nacional de Hidrocarburos, podrá rescindir administrativamente los Contratos para la Exploración y Extracción y recuperar el Área Contractual únicamente cuando se presente alguna de las siguientes causas graves)

118 Ibid.

119 Constitutional Reform, Article 10 Transitory.

120 Decreto por el que se expide la Ley de Ingresos sobre Hidrocarburos, se reforman, adicionan y derogan diversas disposiciones de la Ley Federal de Derechos y de la Ley de Coordinación Fiscal y se expide la Ley del Fondo Mexicano del Petróleo para la Estabilización y el Desarrollo, DOF: 11/08/2014. (Hereafter, Hydrocarbons Income Law.)

121 lbid.

122 Ibid. 
in the case of the production-sharing contracts, the finance ministry will determine whether to include the cost recovery consideration in the agreement. ${ }^{123}$ In sum, even assuming that the ministry of energy decides to go forward with the bidding processes after hearing the CNH's opinion, the finance ministry could set up a fiscal regime that makes the whole project unviable for the private operators. In this case, the CNH does not have the power to convince the finance ministry to modify the economic terms of the contracts. One could easily imagine a scenario where, after a failed bidding process, the incoming president instructs the ministry of energy to assign a field to Pemex. The incoming president could argue that it is in the national interest to develop the resources after the private companies rejected the "fair" economic terms from the state and insisted on trying to get "more" of the nation's riches. Whether Pemex is in a financial and technical condition to develop the particular field, is a different story. However, the legal architecture is there and could readily be deployed for a political cover-up.

\section{Figure 3.2. E\&P Contracts}

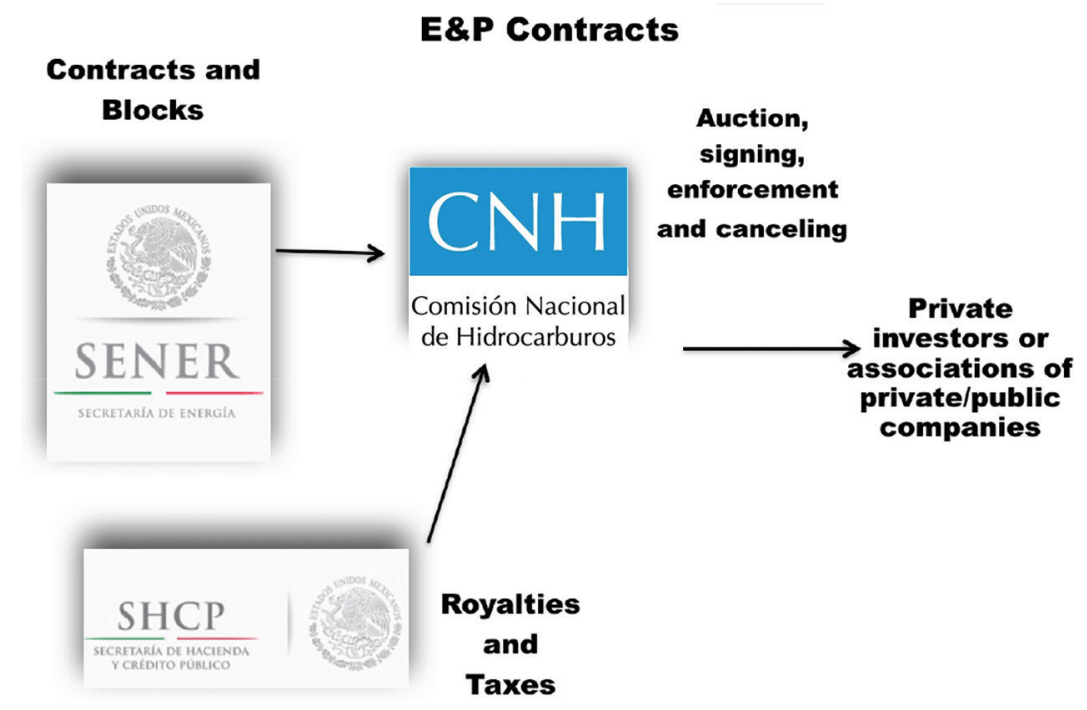

The finance ministry's executive control over the financial terms of the contracts is effectively unlimited, and could derail the economic feasibility of E\&P projects if the new president decides to self-boycott the reform. This policy would not require any constitutional amendment since it is well within the powers of the executive as envisioned in the energy reform.

\section{International Protection of Existing Investments}

As stated above, the $\mathrm{CNH}$ has limited grounds to rescind the contracts without an obligation to compensate the private companies. ${ }^{124}$ The Hydrocarbons Law establishes a procedure in which the private company can challenge the $\mathrm{CNH}$ decision and try to resolve the breach of contractual obligations before it becomes final. ${ }^{125}$ Once the $\mathrm{CNH}$ confirms its decision, the only available legal mean to challenge the rescission is to file an

\footnotetext{
123 Ibid., Article 13.

124 Hydrocarbons Law, Article 20. The private company has 30 days after receiving the $\mathrm{CNH}$ decision to provide evidence and challenge the rescission. After receiving arguments and evidence from the company, the $\mathrm{CNH}$ has 90 days to confirm its decision. If the private company solves the inconsistency, the $\mathrm{CNH}$ can leave without effecting the rescission.
}

125 Ibid. 


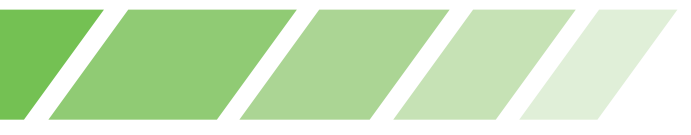

administrative action in Mexican federal tribunals. ${ }^{126}$ According to the Hydrocarbons Law, "as a consequence of an administrative rescission, the Contractor will transfer back to the State the area without any charge, payment, or compensation." ${ }^{27}$ For any other contractual dispute, the E\&P contracts can include alternative dispute resolution mechanisms, including arbitration provisions under international treaties signed by the Mexican state. ${ }^{128}$ For example, if the Mexican government decides to modify the Hydrocarbons Law or the Hydrocarbons Income Law in a way that affects the contractual relationship or the business plans of the companies, the latter could bring a legal action internationally for a breach of International Bilateral Investment Treaties. ${ }^{129}$ The international treaties provide for an arbitral mechanism in neutral forums where the investor could obtain higher amounts of compensation than if they had disputed the issues domestically. ${ }^{130}$

Some of the license contracts signed by Mexico, particular for the deepwater fields, provide additional safeguards to foreign investors. ${ }^{131}$ Although the license agreement specifies that any dispute regarding the administrative rescission determined by the $\mathrm{CNH}$ will be resolved in federal tribunals, it gives investors a right to bring the dispute to an international tribunal for quantifying compensation. For example, the contract with China Offshore Oil Corporation E\&P Mexico provides that "the contract may initiate a proceeding before an international tribunal ... exclusively to determine the existence of compensatory damages and lost profits and, depending on the case, its monetary quantification, that emerges as a consequence of an administrative rescission that is ruled as groundless by the Federal Tribunals." 132 Moreover, according to the contract, the company "will enjoy all of the rights recognized in international treaties signed by the State." 133 This would include the ChinaMexico Bilateral Investment Treaty (China-Mexico BIT) in force since June 6, 2009. ${ }^{134}$ According to Article 1 of this treaty, contracts signed with Mexico cannot be affected by government actions because they fall under the

126 Ibid.

127 Ibid. ("Como consecuencia de la rescisión administrativa, el Contratista transferirá al Estado sin cargo, ni pago, ni indemnización alguna, el Área Contractual. Asimismo, se precederá a realizar el finiquito correspondiente en términos de las disposiciones jurídicas aplicables y de las previsiones contractuales.")

128 lbid., Article 21 ("Tratándose de controversias referidas a los Contratos para la Exploración y Extracción, con excepción de lo mencionado en el artículo anterior, se podrán prever mecanismos alternativos para su solución, incluyendo acuerdos arbitrales en términos de lo dispuesto en el Titulo Cuarto del Libro Quinto del Código de Comercio y los tratados internacionales en materia de arbitraje y solución de controversias de los que México sea parte.")

129 Guillermo J. García Sanchez, "The Hydrocarbons Industry's Challenge to International Investment Law: A Critical Approach," Harvard International Law Journal 57, no. 2 (2016): 475-528, https://ssrn.com/abstract=2820729.

130 Ibid.

131 China Offshore Oil Corporation E\&P Mexico, S.A.P.I. de C.V.; see also note 26.

132 Ibid. at Section 26.4 ("El contratista podrá iniciar un procedimiento ante un tribunal arbitral, en términos de la Clausula 26.5, únicamente parta que se determine la existencia de daños y perjuicios y en su caso, su cuantificación, que resulten de una causal o causales de rescisión administrativa consideradas infundadas por los Tribunales Federales de forma definitiva.")

133 Ibid. at Section 26.9.

134 "Agreement Between the Government of the United Mexican States and the Government of the People's Republic of China on the Promotion and Reciprocal Protection of Investments," http://investmentpolicyhub.unctad.org/Download/TreatyFile/759. 
definition of a protected investment. ${ }^{135}$ These are "contracts where remunerations depends substantially on the production, revenues or profits of an enterprise" and the deepwater fields are located in the Mexican continental shelf, which according to the treaty and international law is considered Mexican territory. ${ }^{136}$

In sum, the international companies can challenge a rescission from the $\mathrm{CNH}$ before federal tribunals. If they win the case, they can bring the claim to an international arbitral tribunal to quantify the compensatory damages and loss of profits. These mechanisms are additional layers of protection that are not specified in the constitution nor the transitory articles or the secondary legislation. In addition to this "domestic" proceeding with an international recourse for quantification, the companies also have access to international arbitral tribunals to resolve any other disputes related to the contract. ${ }^{137}$ International BITs or investment chapters in free trade agreements, such as Chapter 11 of the North American Free Trade Agreement (NAFTA), force Mexico to provide foreign investors with "fair and equitable treatment" (NAFTA Article 1105, or China-Mexico BIT Article 5) and to receive prompt and adequate compensation in the case of expropriation (NAFTA Article 1110, or China-Mexico BIT Article 7). ${ }^{138}$ For example, if a new government decides to cancel existing contracts by enacting new legislation that forces the companies to renegotiate the existing deals with more state-centered legislation, then the companies could bring claims to international investment tribunals. In these international fora, they could allege that they were being treated unfairly and that the government violated their investment "legitimate expectations." 139 They could even argue that by forcing them to renegotiate the deal, the new government's actions are an unlawful expropriation. ${ }^{140}$

Governments in Mexico are aware of the importance of letting international investors know that the state will fulfill its promises to arbitrate these types of disputes in international forums, regardless of who is in power. ${ }^{141}$ Evidence of that is the fact that Mexico recently signed the Convention on the Settlement of Investment Disputes between States and Nationals of Other States (ICSID Convention). This convention created the

135 Ibid., Article 1 ("investment" means the asset owned or controlled by investors of a Contracting Party and acquired in accordance with the laws and regulations of the other contracting Party, listed below: . . interest arising from the commitment of capital or other resources in the territory of a Contracting party to economic activity in such territory, such as under (i) contracts involving the presence of an investor's property in the territory of the other Contracting Party, including turnkey or construction contracts, or concessions, or (ii) contracts where remunerations depends substantially on the production, revenues or profits of an enterprise").

136 Ibid. ("in respect of the United Mexican States, the territory of the United Mexican States including the maritime areas adjacent to its coast, i.e. territorial sea, the exclusive economic zone and the continental shelf, to the extent to which the United Mexican States may exercise sovereign rights or jurisdiction in those areas according to international law."). For a deeper study of investments in the Gulf of Mexico, particularly near the maritime border with the United States, see Guillermo J. García Sanchez and Richard McLaughlin, "The 2012 Agreement on the Exploitation of Transboundary Hydrocarbon Resources in the Gulf of Mexico: Confirmation of the Rule or Emergence of a New Practice?," Houston Journal of International Law 37, no. 3 (2015): 681-792, https://ssrn.com/abstract=2652563.

137 For an extensive review of the mechanisms in the context of NAFTA, see Bradly J. Condon, "Mexican Energy Reform and NAFTA Chapter 11: Articles 20 and 21 of the Hydrocarbons Law and Access to Investment Arbitration," Journal of World Energy Law and Business 9 , no. 3 (2016): 203-19; for the rights of companies in the Mexican legal system, see Guillermo J. García Sanchez, "Las empresas y sus derechos humanos según la Corte" [The human rights of companies according to the Supreme Court of Mexico], NEXOS, El Juego de la Corte, April 14, 2014, https://eljuegodelacorte.nexos.com. $m x / ? p=3737$.

138 Ibid.

139 García Sanchez, supra note 55.

140 Ibid.

141 See Carlos Vejar's comments on the ratification, "Consequences for Mexico After Subscribing to the ICSID Convention," Holland and Knight Newsletter, January 11, 2019, www.hklaw.com/publications/Consequences-for-Mexico-After-Subscribing-to-the-ICSID-Convention-01-11-2018/. 


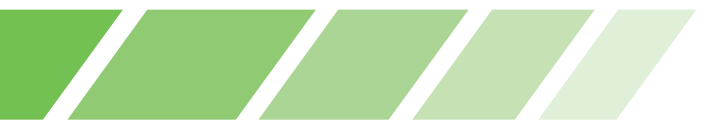

International Centre for Settlement of Investment Disputes (ICSID) to provide investors and states with services and procedural rules for the conciliation and arbitration of their investment differences. ${ }^{142}$ Most important, for investors' rights, the ICSID Convention has a stronger enforcement mechanism than the BITs because it forces states to recognize the pecuniary obligations in the awards "as if it were a final judgment of a court in that State." ${ }^{43}$ There is no need to go through the regular judicial enforcement proceedings prescribed by the New York Convention on the Recognition and Enforcement of Foreign Arbitral Awards. ${ }^{144}$ Even though Mexico was in the top 10 recipient countries of foreign direct investment and had used the ICSID Additional Facilities before, Mexico had been reluctant to sign the ICSID Convention. ${ }^{145}$

\section{Can the New Agencies Control Gulliver?}

In his novel Gulliver's Travels, Jonathan Swift describes how the tiny people of the island of Lilliput subdued a giant who washed up on their shore. Imprisoning Gulliver was only possible after the Lilliputians worked together and left their fights over trivial matters aside. The new agencies created by the energy reform cannot subdue the will of the executive power to further implement the reform, but if they work together, they still hold vital competencies to keep the reform afloat or at least mitigate the pace of radical changes. The example mentioned above of the NHC and its power to enforce and supervise the existing contracts is just one of many.

The reform also created the following agencies that mostly regulate the technical and economical operation of the energy market in Mexico: the National Agency for Industrial Security and Environmental Protection of the Hydrocarbon Sector (ASEA), the National Center for Natural Gas Control (CENEGAS), the National Energy Control Center (CENACE), and the Mexican Oil Fund for Stabilization and Development. Both CENACE and CENEGAS are agencies in charge of ensuring technical operation of the energy market. CENACE has "the operative control of the national electric system," must supervise the operation of the "wholesale electricity market," and most importantly has to ensure that there is a "nondiscriminatory and open access to the national grid and the general distribution lines." 146

With respect to CENEGAS, the agency has the duty to control the "operation of the national pipeline system for the storage and transportation" of natural gas. ${ }^{147}$ CENACE basically takes control of the national grid away from the previous state-owned entity, Comision Federal de Electricidad (CFE). Instead of a state monopoly controlled by CFE, now private actors can compete with the state productive company for the generation and

142 The ICSID Convention has been ratified by 153 states and entered into force on October 14, 1966. For the text of the convention, see https://icsid. worldbank.org/en/Documents/icsiddocs/ICSID\%20Convention\%20English.pdf. For information on the ICSID, https://icsid.worldbank.org/en/.

143 Article 54 (“(1) Each Contracting State shall recognize an award rendered pursuant to this Convention as binding and enforce the pecuniary obligations imposed by that award within its territories as if it were a final judgment of a court in that State. A Contracting State with a federal constitution may enforce such an award in or through its federal courts and may provide that such courts shall treat the award as if it were a final judgment of the courts of a constituent state.")

144 The New York Convention on the Recognition and Enforcement of Foreign Arbitral Awards is one of the oldest international instruments that gives the right to the winning party of an arbitral process to go through a judicial process to have the award recognized in any jurisdiction where the Convention is in force. For more information, see the convention's website at www.newyorkconvention.org.

145 Vejar, "Consequences for Mexico after Subscribing to the ICSID Convention."

146 Article 16 Transitory, ("encargado del control operativo del sistema eléctrico nacional; de operar el mercado eléctrico mayorista; del acceso abierto y no indebidamente discriminatorio a la red nacional de transmisión y a las redes generales de distribución.") 
marketing of electricity. CFE is left only with the transmission and distribution of power, which is considered a public service, but private parties, to a limited extent, may also participate in transmission and distribution activities by contracting with the State. The reform also strengthened the role of the Energy Regulatory Commission (CRE) in its role of granting electricity generation permits, permits in the hydrocarbon industry activities (transportation, storage, distribution, compression, liquefaction, decompression, regasification, marketing, and sale of hydrocarbon products to the public), and permits for the management of integrated systems. In the regulation of the market, these agencies can have an impact on the way the new administration perceives the importance of implementing the reform. For example, for the electricity market, CENACE, the CRE, and the Ministry of Energy regulate the sale of electricity produced in small scale near consumption sites, and that are connected directly to a distribution network (“distributed generation”), such as microgenerators of renewable energy.

Of the new agencies, those with a higher level of autonomy are the CRE and the NHC. These administrative entities are considered decentralized organs ("organos desconcentrados") of the federal government that are recognized by Article 28 of the Constitution as "coordinated regulatory organs" of the energy sector and have autonomy in their functions from the Ministry of Energy. ${ }^{148}$ As such, they have regulatory powers recognized in the Constitution, and although they are constitutionally part of the federal executive power, they do have technical, operative, and budgetary autonomy. ${ }^{149}$ Moreover, the Mexican Senate is involved in the designation of the commissioners of both regulatory agencies. ${ }^{150}$ The president must submit three candidates for each commissioner's seat, and two-thirds of the Senate must choose one among the three. If the Senate fails to select a commissioner after thirty days, then the Executive can designate him/her from the list. ${ }^{151}$ The commissioners can be reelected for the same position once and can only be removed for "grave" causes. ${ }^{152}$ The ASEA is also a decentralized organ but it does have a direct hierarchical dependency from the Ministry of Environment (SEMNARNAT), and it is not recognized in Article 28 of the Constitution as a coordinated regulatory organ in the energy sector. ${ }^{153}$ Moreover, the head of ASEA can be designated and removed directly by the president. ${ }^{154}$

People who are committed to the institutions where they work make a difference when there are changes in the political arena. Thus far, the officers at CRE and NHC have technical profiles, with years of experience, and a deep understanding of their duties to their agencies. Civil servants can hold "Gulliver" accountable if they place themselves above politics and place their trust in institutions. They can make it harder for politicians to implement profound policy changes; they can advise the incoming party against backtracking specific policies that could hurt the institutions or the country; they can become the resistance inside the administration that

148 Article 28 of the Constitution ("El poder Ejecutivo contara con los órganos reguladores coordinados en materia energética denominados Comisión Nacional de Hidrocarburos y Comisión Reguladora de Energía") http://www.diputados.gob.mx/LeyesBiblio/pdf/1_150917.pdf

149 Article 10 Transitory, b) and c); Article 12 Transitory; for an explanation of the diference between decentralized and de-concentrated organs see, Josefina Cortes Campos, La administración pública: una categoría normativa en construcción, in CIEN ENSAYOS PARA EL CENTENARIO. CONSTITUCIÓN POLÍTICA DE LOS ESTADOS UNIDOS MEXICANOS, Tomo 2 (2017), p. 77

150 Article 13 Transitory.

151 Ibid.

152 Ibid.

153 Articles 24 and 27, Ley de la Agencia Nacional de Seguridad Industrial y de Protección al Medio Ambiente del Sector Hidrocarburos. 154 Ibid. 


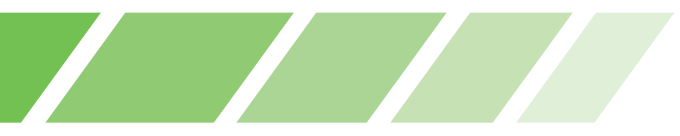

makes it hard for the incoming giant to stir the helm too quickly away from the set curse. Mexico has had such profiles in ministries such as the Ministry of Treasury and the Ministry of Foreign Affairs. These two have the lowest turnover rates of high-level officers in the Mexican administration. Particularly the latter one has a deeply rooted culture of institutional loyalty, backed by legislation that fosters meritocracy above politics, and ensures that the diplomatic core follows the pre-established principles and traditions of Mexican diplomacy even when facing new presidents and politically appointed ministers of foreign affairs. The new energy agencies do not have similar laws that protects them from political interference, and the officers are just starting to create an institutional culture, but there is hope that in the long run they will be able to survive any changes and be a pillar of stability. Ultimately, any new administration needs to fill the positions in these organisms and Mexico has few professionals with the expertise in the open energy market.

As part of the energy reform, the national council for scientific and technological activities (CONACYT) and the Ministry of Energy control a public trust in charge of financing research related to the implementation of the energy sector and for creating human capital specialized in the area. ${ }^{155}$ As such, the government has the money available to build a new brand of energy government officials trained by the best institutions in Mexico and abroad. These resources must be protected and employed adequately. Mexico recently faced corruption scandals related to the misuse of research related funds that ended up financing political campaigns using contracts with public universities. ${ }^{156}$ The public fund for the creation of technology and human capital for the implementation of the energy reform is essential for staffing the newly created agencies. The potential for adequate leadership in the energy sector is there, and it is up to the current administration to make sure that it is not lost in another scandal.

The leadership of public officials has been fundamental in the implementation of the reform. Existing leadership at both the CRE and NHC is praised for their transparency, professionalism, and openness to dialogue with the industry. If a new party comes into power, the existing energy officers could peer up and resist broad changes within the administration. Moreover, they should recommend the continuation of the programs that finance research, technologies, and human capital that ensures that the reform is here to stay. A common front can hold Gulliver to the ground, but division and tribalism can open up the gates for him/her to flood the island.

\section{Conclusion}

When it comes to the transitional provisions of the reform, the drafters of the constitutional amendment seemed to have forgotten a common Mexican folk expression: no hagas cosas buenas que parecen malas, or "don't do good things that give the impression of being bad things." Instead of providing for the reform's most important elements (the rights of the private companies) in the text of the constitution, they drafted them in the transitory articles with the expectation that doing so would be less controversial. This effort to avoid controversy while still paying lip service to the Mexican revolutionary spirit only gave ammunition to the reform's detractors to fight the transitional articles and the secondary legislation in courts. Hence, it is a false idea that the reform is

155 CONACYT - SENER / Hidrocarburos, https://www.conacyt.gob.mx/index.php/fondos-sectoriales-constituidos2/item/conacyt-senerhidrocarburos

156 Albison Linares, “El dinero se iba a un agujero negro': el esquema de corrupción que compromete al gobierno de México, The New York Times, Sept 5, 2017, https://www.nytimes.com/es/2017/09/05/el-dinero-se-iba-a-un-agujero-negro-el-esquema-de-corrupcion-quecompromete-al-gobierno-de-mexico/ 
"bulletproof" because it is constitutional. There is no need to amend the constitution to fight the nature of the contracts in federal courts, because the term concession - which is prohibited by the constitution-is not defined. In fact, the existing licenses look very similar to modern-day concessions around the globe.

The drafters of the Mexican energy reform assumed that they would remain in power for long enough to continue to implement the reform, or at least assumed that future administrations would agree with their energy policies. They suffered from a political arrogance reflected in the legal architecture of the reform. Instead of isolating the future of the energy sector from political transitions, they concentrated the power of long-term implementation in the hands of the executive. The new bodies, like the $\mathrm{CNH}$, have limited powers to influence how the state will develop this strategic sector. They are there to assist in the implementation and provide opinions. But ultimately, the man or woman sitting in Los Pinos has the last word on whether the country will adhere to the vision of the current administration or whether he or she will choose to halt the reform. The current administration somehow missed one of the crucial lessons of the modern constitutional order: if a long-standing implementation is what you seek, make sure you isolate the institutions from political cycles. Do not concentrate power with elected officials. In the short run, this might mean that you will lose some levels of control, but in the long run, you will have ensured that the changes will survive the political transitions.

If the existing hydrocarbon developments were already in the production stage; if the flow of oil was helping Mexico to reduce its national debt, lowering the price of gas and electricity; if the new private companies were already hiring nationals in a substantial number and helping to reduce unemployment in specific regions-if all of these were true, then the energy reform would have the most critical insurance policy against political changes. It would already be yielding the benefits envisioned by its designers. Unfortunately, these benefits are not yet visible to the general population, and except for the bonus payments, the revenues are not flowing in levels that would isolate the new "golden hen" from interference.

However, this does not mean that the existing contracts will be renegotiated or canceled. There are many reasons for the new president to maintain them and wait for the projects to yield positive economic results. After all, Pemex production has been in decline for the past 13 years, and the government needs the additional flows of revenue that the E\&P contracts are projected to yield. Canceling them without any justification established in the contractual terms and the law would mean that the state would have to compensate the investors for their losses and that it would not benefit from the much-needed investment in the upstream sector. Only the CNH, according to the preestablished set of causations, can cancel the contracts on behalf of the government without violating investors' rights. However, this fact in no way means that the government will have to open new projects to private participation or call new auctions. Consequently, the following key policy recommendations should be kept in mind:

- Protect CNH independence. Even though the commission cannot determine whether a future auction will take place, it does control the existing agreements. It is fundamental to ensure that it is as isolated from the political process as possible. 


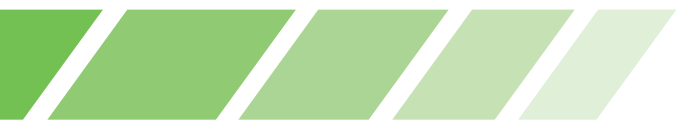

- Transparency. The $\mathrm{CNH}$ and the ministries that participate in the implementation of the energy reform must be extremely cautious in maintaining a good public perception; in that process, transparency is essential. If financial and production indicators are unclear or contradicted by other data, or if the auctions are tainted by accusations of corruption, it will become easier for the next president to halt the reform's implementation. The best defenders of the reform are numbers to prove that it is generating revenue and benefiting the population.

- People matter. It will be up to the incoming Congress to ratify the new members of the CNH. The few controls that the $\mathrm{CNH}$ has over the development of the contracts and the determination of assignments must be exercised by people who have a technical background in the industry and are less subject to political influence. Moreover, the government must continue to invest in human capital that fills agency vacancies. The new generation of government energy experts should not be primarily former Pemex or CFE officials as they are today; they should be a new generation, trained in depoliticized environments and in the logic of technical independence from the electoral cycles.

- Open dialogue. The existing administration has a responsibility to the industry to engage in a dialogue with whoever ends up being the new president. As opposed to trying to advance as many auctions as possible before December 1, when the new president takes office, the current administration should sit down with the existing candidates, the business community, and the agencies to go over the implementation of the reform. The worst scenario is to give additional political weapons to any new government by accelerating the implementation and risking the chance that the bidding process appears corrupt or fraudulent.

- Coordinating decisions. Any decision taken by the $\mathrm{CNH}$ or the ministries that could affect the existing contracts should be taken in coordination with the ministry of economy's office in charge of international negotiations and litigation. Mexico has one of the most renowned team of public officials that specialize in the negotiation of bilateral investment treaties and the litigation of investor-state disputes. If Mexico wants to avoid facing international claims, the team at the ministry of economy should be involved in the decisionmaking process to advise the other agencies on plausible litigation risks.

- Ratification of the ICSID Convention. Even though Mexico has an excellent international reputation for paying investors after losing an international investment claim, now that the government has decided to sign the convention, it is necessary to ratify it before the next government takes office. Considering the political climate in Mexico today, a failure to ratify the convention would send the wrong signal to investors regarding the state's commitment to help enforce arbitral investment awards. 